\title{
Renal Sparing Surgery Using Focus Ultracision Harmonic Scalpel in Patients with Bilateral Wilms' Tumor: Case Report
}

\author{
Murat Alkan, Cemal Parlakgümüş, Serdar Hilmi İskit, Recep Tuncer, Hasan Okur, Ünal Zorludemir \\ Department of Pediatric Surgery, Çukurova University Faculty of Medicine, Adana, Turkey
}

\begin{abstract}
Background: Bilateral Wilms' tumor is rare and surgical treatment requires an individual approach. Surgical approach to the tumors located in the central part of the kidney represents a major challenge and nephrectomy is usually essential. Renal sparing surgery is difficult in such cases.

Case Report: We describe a 3 year-old female patient with bilateral Wilms' tumor arising in the central localisation of the right and foci in the left kidney enucleated successfully with a simple and comfortable renal preserving operative technique using Focus Ultracision Harmonic Scalpel.

Conclusion: In cases when tumors are located in the central part of the kidney and partial nephrectomy is consequently very difficult, the use of a Focus Ultracision Harmonic Scalpel provides easy dissecting, enucleation, and excision of the tumor.
\end{abstract}

Key Words: Bilateral Wilms' tumor, renal sparing, harmonic

Received: 25.08 .2012

Accepted: 20.11.2012

\section{Introduction}

Wilms' tumor accounts for about $5 \%-10 \%$ of all paediatric malignancies (1); Bilateral Wilms' Tumor (BWT) accounted for $5 \%$ of all patients registered to the National Wilms Tumor Study Group (NWTSG) (2). Although the management of a child with BWT is very challenging, surgical resection of the tumor remains the cornerstone of the treatment while preserving renal function. The aim of this study is to present easily performed enucleation of a central tumor in BWT with the Focus Ultracision Harmonic Scalpel (HS) (Ethicon EndoSurgery Inc., Cincinnati, OH, USA).

\section{Case Report}

A 3 year-old female patient was referred to our clinic with BWT. Ultrasonographic evaluation revealed a $31 \times 35 \mathrm{~mm}$ tumor in the central part of the right and 9x8 mm tumor coming out of the upper pole of the left kidney. According to NWTSG recommendations, pre-operative 7-cure chemotherapy was given. After chemotherapy, control computed tomography showed that the lesion was regressed in the left kidney and a mass with a diameter of $2 \mathrm{~cm}$ remained in the central part of the right kidney. During laparotomy, pale residue foci in the upper pole of the left kidney and the mass in the central part of the right kidney were examined. First of all, pale residue foci were marked out with a rim of healthy parenchyma with electrocautery. Then, with HS, all foci were enucleated from the left kidney (Figures 1 and 2); subsequently, the right kidney was fully exposed. The renal vessels and the pelvis were identified and controlled. Marking with electrocautery, with a margin of normal parenchyma around the central tumor, the tumor was enucleated with HS comfortably (Figures 3 and 4). Even though there was no urinary leakage or bleeding, we filled the defect with omentum to provide additional haemostasis and block the urinary leakage. The post-operative period was uneventful.

\section{Discussion}

The treatment of BWT aims at maximal conservation of uninvolved renal parenchyma, in order to salvage renal function. Surgical treatment consisted of unilateral nephrectomy with contralateral partial nephrectomy if partial nephrectomy is possible in one of the two kidneys. Tumors located in the central part of the kidney do not allow partial nephrectomy. Then, as a last resort, enucleation of the tumor or bilateral nephrectomy can be considered. From a surgical standpoint, enucleation of the tumor means performing tumourectomy with a safe margin that preserves functional renal parenchyma. In BWT, the goal of enucleation should be excision of all tumors with safe margins in both kidneys. Recent studies revealed significant postoperative morbidity, recurrence and mortality, even with partial nephrectomy for BWT. Because of significant postoperative morbidity, the management has evolved from partial nephrectomy to renal-sparing surgery $(3,4)$.

HS can be used for both open and endoscopic surgical procedures; it cuts through tissue by vibrating in the range of $55.500 \mathrm{~Hz}$. The vibration cuts through the tissue and seals it using protein denaturation, rather than heat. The shape of the instrument is like a 'Kelly clamp', and 


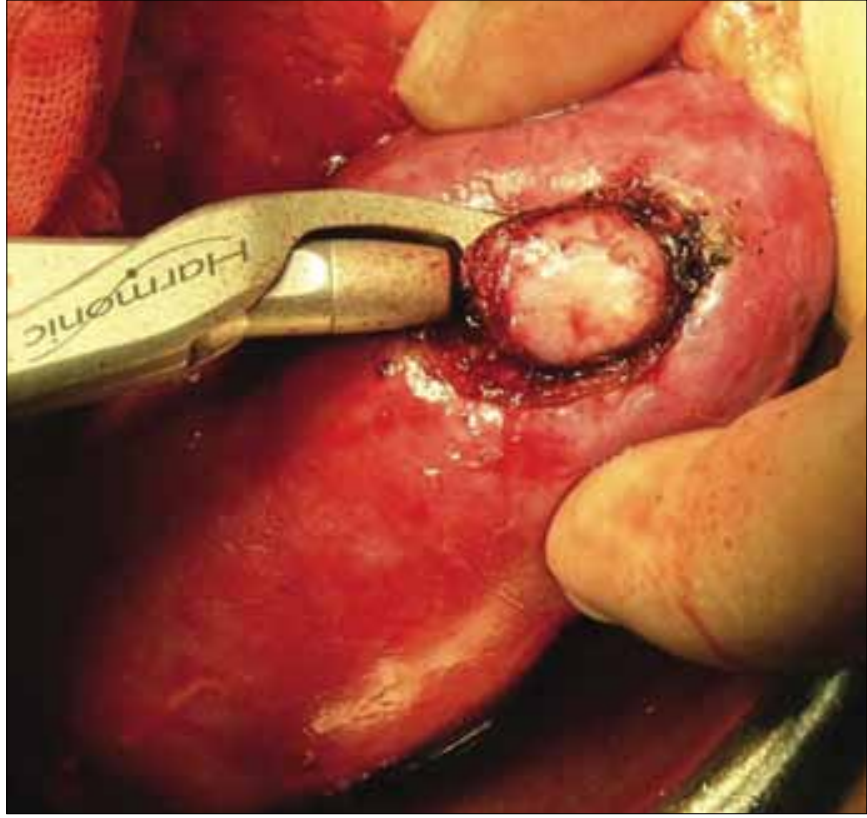

Figure 1. Enucleation of the focus with Focus Ultracision HS from the left kidney.

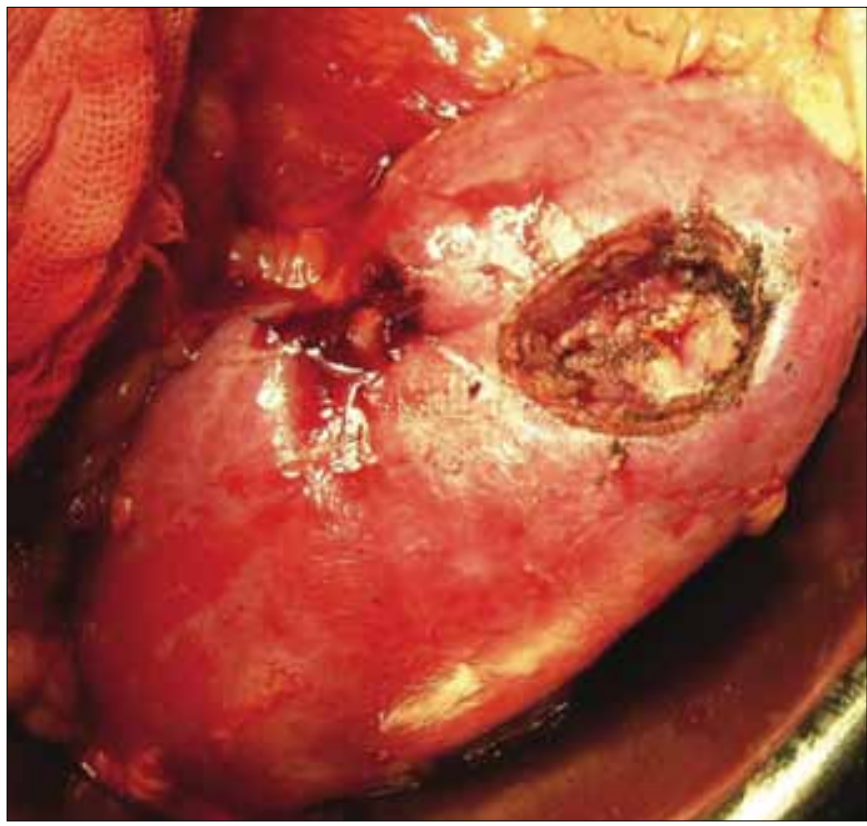

Figure 2. After enucleation of the focus with Focus Ultracision HS.

facilitates easy dissection in a small surgical area. Several reports have been published describing the safety, advantages and experience of HS usage for surgeries in several anatomical regions, such as thyroid surgery (5), cholecystectomy (6), neck lymphadenectomy (7), radical mastectomy (8), partial splenectomy (9), gastric surgery (10) and renal tumor operations which preserve the kidney (11-13). In our case, the central location of the tumor forced us to perform renal-sparing surgery. Focus Ultracision HS facilitated comfortable dissection of the central located tumor without bleeding or urinary leakage.

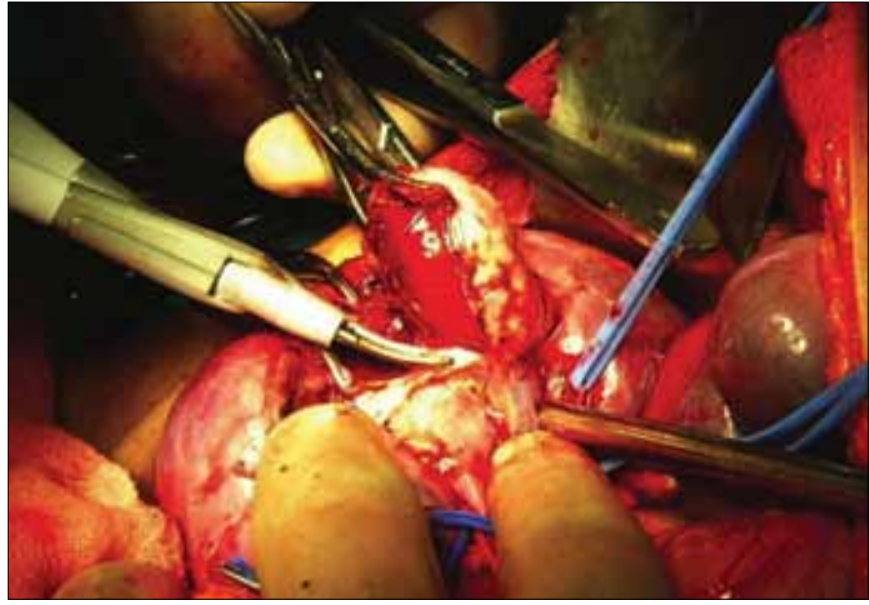

Figure 3. Enucleation of the tumor with Focus Ultracision HS from the right kidney.

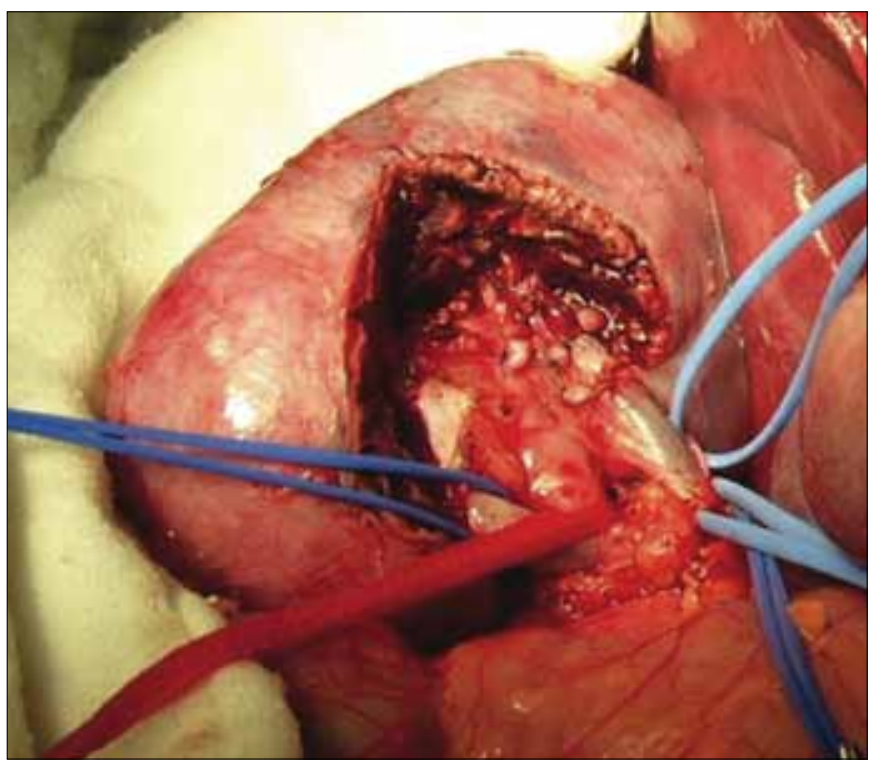

Figure 4. After enucleation of the tumor with Focus Ultracision HS.

In cases when tumors are located in the central part of the kidney and partial nephrectomy is consequently very difficult, the use of HS provides easy dissection, enucleation, and excision of the tumor.

Ethics Committee Approval: Ethics committee approval was received for this study.

Informed Consent: Written informed consent was obtained from the patient.

Peer-review: Externally peer-reviewed.

Author contributions: Concept - M.A.; Design - M.A., C.P., S.H.I.; Supervision - Ü.Z., R.T., S.H.i.; Resource - S.H.i.; Materials - M.A., C.P., S.H.i.; Data Collection\&/or Processing - M.A., S.H.I., C.P; Analysis\&/ or Interpretation - M.A. C.P., S.H.I.; Literature Search - M.A.; Writing M.A., S.H.i.; Critical Reviews - S.H.i., U.Z.

Conflict of Interest: No conflict of interest was declared by the authors.

Financial Disclosure: No financial disclosure was declared by the authors. 


\section{References}

1. Young JL Jr, Heise HW, Silverberg E, Myers Mh. Cancer incidence, survival and mortality for children under 15 years of age. American Cancer Society Professional Education Publication, New York, September 1978

2. Montgomery BT, Kelalis PP, Blute ML, Bergstralh EJ, Beckwith JB, Norkool P, et al. Extended follow-up of bilateral Wilms tumor: results of National Wilms Tumor Study. J Urol 1991;146:514-18.

3. Cooper CS, Jaffe WI, Huff DS, Canning DA, Zderic SA, Meadows AT, et al. The role of renal salvage procedures for bilateral Wilms tumor: a 15-year review. J Urol 2000;163:265-8. [CrossRef]

4. Davidoff AM, Giel DW, Jones DP, Jenkins JJ, Krasin MJ, Hoffer FA, et al. The feasibility and outcome of nephron- sparing surgery for children with bilateral Wilms tumor. Cancer 2008; 112: 2060-70. [CrossRef]

5. Ecker T, Carvalho AL, Choe JH, Walosek G, Preuss KJ. Hemostasis in thyroid surgery: harmonic scalpel versus other techniques-a meta-analysis. Otolaryngol Head Neck Surg 2010;143:17-25. [CrossRef]

6. Westervelt J. Clipless cholecystectomy: broadening the role of the harmonic scalpel. JSLS 2004;8:283-5.
7. Miccoli P, Materazzi G, Fregoli L, Panicucci E, Kunz-Martinez W, Berti P. Modified lateral neck lymphadenectomy: prospective randomized study comparing harmonic scalpel with clamp-and-tie technique. Otolaryngol Head Neck Surg 2009;140:61-4. [CrossRef]

8. Deo SV, Shukla NK, Asthana S, Niranjan B, Srinivas G. A comparative study of modified radical mastectomy using harmonic scalpel and electrocautery. Singapore Med J 2002;43:226-8.

9. Godiris-Petit G, Goasguen N, Munoz-Bongrand N, Cattan P, Sarfati E. Laparoscopic partial splenectomy using the Harmonic Scalpel. Two case reports. J Chir (Paris) 2007;144:339-41. [CrossRef]

10. Inoue K, Nakane Y, Michiura T, Yamada M, Mukaide H, Fukui J, et al. Ultrasonic scalpel for gastric cancer surgery: a prospective randomized study. J Gastrointest Surg 2012;16:1840-6. [CrossRef]

11. Millar AJ, Davidson A, Rode H, Numanoglu A, Hartley PS, Daubenton JD, et al. Bilateral Wilms' tumors: a single-center experience with 19 cases. J Pediatr Surg 2005;40:1289-94. [CrossRef]

12. Zhang $X$, Li HZ, Ma X, Zheng T, Li LC, Ye ZQ. Retroperitoneal laparoscopic nephron-sparing surgery for renal tumors: report of 32 cases. Urology 2005;65:1080-4. [CrossRef]

13. Harmon WJ, Kavoussi LR, Bishoff JT. Laparoscopic nephronsparing surgery for solid renal masses using the ultrasonic shears. Urology 2000;56:754-9. [CrossRef] 